\title{
MT1G Hypermethylation: A Potential Prognostic Marker for Hepatoblastoma
}

\author{
LUIS H. T. SAKAMOTO, BEATRIZ DE CAMARGO, MARIANA CAJAIBA, FERNANDO A. SOARES, AND ANDRÉ L. VETTORE \\ Ludwig Institute for Cancer Research, São Paulo Branch [L.H.T.S., A.L.V.], São Paulo 01323-903, Brazil; Departments of Pediatrics \\ [B.D.C.] and Pathology [M.C., F.A.S.], A. C. Camargo Hospital, São Paulo 01509-010, Brazil; Department of Science Biology [A.L.V.], \\ Federal University of São Paulo (UNIFESP), São Paulo 04039-032, Brazil
}

\begin{abstract}
Hepatoblastoma comprises only $1 \%$ of all cancers in childhood. Because of its low frequency, a small number of prognostic factors are described in hepatoblastoma and most of them are related to resectability. Microarray studies showed a large number of underexpressed genes in hepatoblastoma. Because aberrant DNA methylation has been recognized as an alternative mechanism for tumor suppressor gene inactivation, this could be involved with gene downregulation in these tumors. Despite the rarity of hepatoblastoma, this study evaluated the methylation pattern of 25 genes in 20 paraffin-embedded tumor specimens and five non-neoplastic liver samples (normal control) by quantitative methylation-specific PCR (QMSP). The examination of the methylation profile of hepatoblastoma samples and normal liver specimens revealed a high tumorspecific DNA hypermethylation in the promoter regions of five genes (APC, CDH1, MT1G, RASSF1A, and SOCS1). Furthermore, MT1G hypermethylation showed a significant correlation with poor prognosis of patients with hepatoblastoma. This study represents the first quantitative evaluation of promoter hypermethylation in hepatoblastoma and demonstrated that aberrant methylation is a frequent event in this malignancy. Furthermore, our data provide evidence that $M T 1 G$ hypermethylation may be useful as prognostic indicator for this disease and suggest that patients with hepatoblastoma may benefit from demethylating drug treatments. (Pediatr Res 67: 387-393, 2010)
\end{abstract}

$\mathrm{H}$ epatoblastoma is the most common malignant liver tumor in childhood. Data from Surveillance Epidemiology and End Results (SEER) estimate an incidence of 0.5-1.5 cases per million children per year, which accounts for $79 \%$ of hepatic neoplasia in children younger than $15-\mathrm{y}$ and for $1 \%$ of all cancers in this age group (1).

Few prognostic factors are available for hepatoblastoma. The most important features appear to be low alphafetoprotein level, pure fetal histology, gross resectability of the tumor, and the presence of metastases in the lung and small cell undifferentiated tumor type. In fact, complete surgical resection remains the most important intervention required for long-term survival $(2,3)$.

Received August 3, 2009; accepted November 14, 2009

Correspondence: André L. Vettore, Ph.D., Laboratório de Genética do Câncer, Departamento de Ciências Biológicas, Universidade Federal de São Paulo (UNIFESP), Rua Pedro de Toledo, 669, $11^{\circ}$ andar, São Paulo, Brazil 04039-032; e-mail: andre.vettore@gmail.com

Supported by Fundação de Amparo à Pesquisa do Estado de São Paulo (FAPESP) grant 06/61572-8 (A.L.V.).

L.H.T.S. is recipient of fellowship from Fundação António Prudente (FAP).
Although some chromosomal alterations have been found in hepatoblastoma (1q, 2q, 7q, 8, 17q, and 20 amplifications), no etiological relationship or prognostic value could be attributed to these findings. The majority of tumors from patients with hepatoblastoma do not show any detectable chromosomal anomaly $(2,4)$.

DNA methylation, catalyzed by DNA methyltransferases, involves the addition of a methyl group to the carbon 5 position of the cytosine ring in $\mathrm{CpG}$ dinucleotides (5). This is associated with several changes in chromatin structure, including the regulation of histone methylation and acetylation and the recruitment of proteins to the methylated sites, which usually leads to the obstruction of the promoter, hindering gene transcription and subsequently silencing the gene (6). There is increasing evidence that in addition to genetic aberrations, the epigenetic processes play a major role in carcinogenesis. Aberrant methylation (hypermethylation) of gene promoter regions is the most widely studied epigenetic abnormality in human malignancies. This epigenetic event acts as an alternative to mutations and deletions to disrupt tumor suppressor gene function (7).

Aberrant promoter methylation has been described for several genes in various malignant diseases, and each tumor type may have its own distinct pattern of methylation $(8,9)$. It was reported previously that gene hypermethylation may occur in patients with hepatoblastoma. Harada et al. (10), analyzing aberrant promoter hypermethylation in pediatric tumors and cell lines, observed RASSF1A hypermethylation in $19 \%$ of hepatoblastoma speci-

Abbreviations: $\boldsymbol{A C T B}$, beta actin; $\boldsymbol{A I M 1}$, absent in melanoma 1; $\boldsymbol{A P C}$, adenomatous polyposis coli; $\boldsymbol{C A L C A}$, calcitonin-related polypeptide alpha; CCNA1, cyclin A1; CCND2, cyclin D2; CDH1, cadherin 1, type 1, E-cadherin

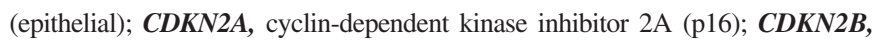
cyclin-dependent kinase inhibitor 2B (p15); DAPK, death-associated protein kinase 1; ESR1, estrogen receptor 1; GSTP1, glutathione S-transferase pi; MGMT, O-6-methylguanine-DNA methyltransferase; MINT31, methylated in tumors 31; $\boldsymbol{M L H 1}$, mutL homolog 1, colon cancer, nonpolyposis type 2; MT1G, metallothionein 1G; MSP, methylation-specific PCR; P14ARF, cyclin-dependent kinase inhibitor 2A; PMR, percent of methylated reference; $\boldsymbol{P T G S 2}$, prostaglandin-endoperoxide synthase 2; $\boldsymbol{Q M S P}$, quantitative MSP;

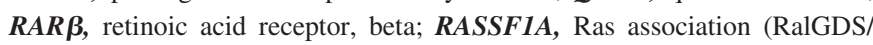
AF-6) domain family 1; RB1, retinoblastoma 1; SCGB3A1, secretoglobin, family 3A, member 1; SFRP1, secreted frizzled-related protein 1; SIOPEL, The International Childhood Liver Tumour Strategy Group; SOCS1, suppressor of cytokine signaling 1; THBS1, thrombospondin 1; TIMP3, TIMP metallopeptidase inhibitor 3 
mens. Shim et al. (11) showed that $50 \%$ of 24 patients with hepatoblastoma had hypermethylated $C D K N 2 A$. Nagai et al. (12) found that $\mathrm{CpG}$ islands in promoter region of SOCS1 gene were hypermethylated in seven of 15 hepatoblastoma samples examined. It is important to note that all of these studies focused on few genes and were conducted using conventional methylationspecific PCR (MSP) technique.

Therefore, the aims of this study were a) to determine the promoter methylation status of 25 genes in hepatoblastoma using the real-time quantitative MSP (QMSP) technology, which is more sensitive than conventional MSP, b) to compare the methylation status with clinical characteristics of the patients, and c) to evaluate if this kind of molecular analysis could be useful as a prognostic marker.

\section{MATERIALS AND METHODS}

Patients, sample collection, and DNA preparation. The study involved 20 patients with hepatoblastoma treated between 1984 and 2005 at Hospital do Cancer A. C. Camargo, São Paulo, Brazil. A majority of the patients (95\%) were submitted to a neoadjuvant chemotherapy scheme. Formalin-fixed and paraffin-embedded (FFPE) tumor samples were obtained from pathology archives. Tissue sections were stained with hematoxylin/eosin according to standard procedures and all cases were revised and the diagnosis was confirmed. Five FFPE specimens of fetal liver from miscarriages (25-36 wk) were included in the study as normal controls.

The study was approved by the Ethics Committee of the Hospital do Câncer A. C. Camargo and performed in accordance with the ethical guidelines of the 1975 Declaration of Helsinki.

Microdissection was applied to paraffin-embedded sections to enrich tumor cell content to $>90 \%$. After microdissection, genomic DNA was extract from 10 tissue sections using the DNA Mini Kit (Qiagen, Hilden, Germany), following the manufacturer's recommendations.

Bisulfite treatment. Bisulfite treatment of DNA converts unmethylated cytosines to uracil, but the methylated ones remain as cytosines. Sodiumbisulfite conversion of $2 \mu \mathrm{g}$ of DNA was performed by the modification of a previously described method (13). In brief, $2 \mu \mathrm{g}$ of DNA from each sample was denatured in $0.2 \mathrm{M} \mathrm{NaOH}$ for $20 \mathrm{~min}$ at $50^{\circ} \mathrm{C}$ (in a total volume of 20 $\mu \mathrm{L}$ ). The denatured DNA was diluted in $500 \mu \mathrm{L}$ of a freshly made bisulfite solution $(2.5 \mathrm{M}$ sodium metabisulfite, $125 \mathrm{mM}$ hydroquinone, $350 \mathrm{mM}$ sodium chloride, $\mathrm{pH} \mathrm{5.0)}$ and incubated for $3 \mathrm{~h}$ at $70^{\circ} \mathrm{C}$ in the dark. Bisulfite-modified DNA was purified using the Wizard DNA Clean-Up System (Promega, San Luis Obispo, CA) according to the manufacture's instructions and eluted in $45 \mu \mathrm{L}$ of water at $80^{\circ} \mathrm{C}$. After treatment with $\mathrm{NaOH}$ (final concentration $0.3 \mathrm{M}$ ) for $10 \mathrm{~min}$ at room temperature, the treated DNA was precipitated by the addition of $75 \mu \mathrm{L}$ of ammonium acetate (5M), 2.5 volumes of ethanol, and $2 \mu \mathrm{L}$ of glycogen $(5 \mathrm{mg} / \mathrm{mL})$. Each resulting DNA pellet was washed with $70 \%$ ethanol, dried, dissolved in $110 \mu \mathrm{L}$ of water, and stored at $-80^{\circ} \mathrm{C}$.

Gene selection. A total of 25 genes were selected for QMSP-based examination of methylation abnormalities. All the genes evaluated in this study showed tumor suppressor activities and their silencing could contribute to tumorigenesis process. CCNA1, CCND2, CDKN2A, CDKN2B, P14ARF, $R B 1$, and SOCS1 are involved in cell cycle control, $C D H 1$ in cell adhesion, $P T G S 2$ in the regulation of inflammatory response, ESR1, APC, DAPK, RASSF1A, RAR, TIMP3, and THBS1 in signal transduction processes, GSTP1 in cell detoxification, MGMT and MLH1 in DNA repair, CALCA and $M T 1 G$ in cell-cell signaling processes, and SFRP1 and SCGB3A1 in cell differentiation and proliferation. The function of AIM1 is not yet well understood. MINT31 is a chromosomal region frequently methylated in human cancers. It has been shown that these genes are affected by aberrant promoter methylation in association with transcription silencing in different types of human malignancies.

Quantitative methylation-specific PCR analyses. Bisulfite-modified DNA was used as a template in fluorogenic QMSP assays carried out in a final volume of $25 \mu \mathrm{L}$ in 96-well plates in a ABI Prism SDS 7000 (Applied Biosystems, Foster City, CA). PCR was performed in separate wells for each primer/probe set and each sample was run in triplicate. The final reaction mixture contained $3 \mu \mathrm{L}$ of bisulfite-modified DNA, $1.2 \mu \mathrm{M}$ of forward and reverse primers, $200 \mathrm{nM}$ probe, $0.5 \mathrm{U}$ of platinum Taq polymerase (Invitrogen, Frederick, MD), $200 \mu \mathrm{M}$ dNTPs, $16.6 \mathrm{mM}$ ammonium sulfate, $67 \mathrm{mM}$ Trizma, $6.7 \mathrm{mM}$ magnesium chloride $(2.5 \mathrm{mM}$ for CDKN2A), $10 \mathrm{mM}$ mercaptoethanol, 0.1\% DMSO, and $1 \times$ ROX dye (Invitrogen, Frederick, MD). PCR was conducted with the following conditions: $95^{\circ} \mathrm{C}$ for $2 \mathrm{~min}$, followed by 45 cycles at $95^{\circ} \mathrm{C}$ for $15 \mathrm{~s}$ and $60^{\circ} \mathrm{C}$ for $40 \mathrm{~s}$.

Each plate included patient DNA samples, multiple water blanks, a negative control (normal leukocyte DNA), and serial dilutions (90-0.009 ng) of a positive control for constructing the calibration curves on each plate. Leukocyte DNA from a healthy individual was methylated in vitro with SssI methyltransferase (New England Biolabs Inc., Beverly, MA) to generate completely methylated DNA at all $\mathrm{CpG}$ and used as positive control.

Primers and probes were designed to specifically amplify the promoter regions of the 25 genes of interest and the internal control gene, ACTB (Table 1) (14-23). The percent of methylated reference (PMR) was calculated according to previously reported equation (methylated target-gene quantification in the sample/ACTB quantification in the sample)/(methylated targetgene quantification in the reference/ACTB quantification in the reference) (20). The reference sample consisted of SssI methyltransferase-treated DNA used for the standard curve and was amplified as a reaction control in all PCR plates.

Cases were scored as positive if a PMR value of $\geq 0.05 \%$ was obtained. This cutoff was chosen for being clinically relevant and also to exclude very low-level background readings that can occur in some samples.

Statistical analysis. SPSS 10.0 (Statistical Package for Social Science) for Windows was used for all statistical analyses. Descriptive statistics were used to summarize study data. Statistical significance was defined as a two-tailed $p$ value $\leq 0.05$. Comparisons between clinical-demographic variables and methylation patterns were performed using the $\chi^{2}$ test or Fisher's exact test.

Survival curves were estimated using the Kaplan-Meier method. Survival data were censored for patients alive at the last observation. The log-rank test was used to compare survival outcomes. The univariate Cox regression model was used to evaluate the methylation level influence on the overall survival (OS).

\section{RESULTS}

Patient characteristics and clinical predictors. The patient clinical characteristics are summarized in the Table 2. The age at diagnosis ranges from 0.36 to 83.68 mo (mean of 23.89 mo). Boys $(65 \%)$ were more affected. Time of symptoms ranges from 0 to 12 mo (mean of $3 \mathrm{mo}$ ).

Eight-five percent of patients had The International Childhood Liver Tumour Strategy Group (SIOPEL) PRETEXT III and IV disease (24). Metastasis at diagnosis was detectable in six of the 20 patients $(30 \%)$ and the lung was the most frequent site. Alpha-fetoprotein level at diagnosis was obtained from 16 patients and two of them showed $<100 \mathrm{ng} / \mathrm{dL}$ and died of disease. In 19 of the 20 patients (95\%), the treatment protocol was based on neoadjuvant chemotherapy followed by tumor resection and adjuvant chemotherapy. The chemotherapy schema was cisplatin/carboplatin/doxorubicin in $50 \%$ of the cases, whereas cisplatin/doxorubicin was used in $45 \%$ of patients. Only one (5\%) patient was submitted to cisplatin monotherapy. According to Radiologic WHO criteria, $60 \%$ of the cases exhibited partial response to the chemotherapy treatment, whereas $20 \%$ showed stable disease. Surgical resectability included partial hepatectomy (70\%), segmentectomy (10\%), and liver transplantation (20\%). Mixed histologic subtype was the most frequent (75\%). The fetal component was present in $85 \%$ of the cases.

Quantitative methylation-specific PCR in hepatoblastoma. The first approach was to verify the methylation pattern of the 25 target genes in 10 tumor samples (pilot group). There was no methylation of AIM1, CCNA1, CDKN2A, DAPK, MGMT, MINT31, MLH1, P14ARF, RB1, and THBS1 in the samples tested and hypermethylation of CALCA (20\%), CDKN2B (20\%), ESRI (20\%), GSTPI (10\%), RAR 3 (30\%), SFRPI (20\%), and TIMP3 (20\%) were rare events. Conversely, APC (60\%), CCND2 (50\%), CDH1 (50\%), MTIG (70\%), PTGS2 
Table 1. Primers and probes used in the QMSP assays

\begin{tabular}{|c|c|c|c|c|}
\hline Gene & Reference & Forward 5-3' & Probe 6FAM 5-3'TAMRA & Reverse 5-3' \\
\hline$A C T B$ & 14 & TGGTGATGGAGGAGGTTTAGTAAGT & $\begin{array}{l}\text { ACCACCACCCAACACACAATAACAA } \\
\text { ACACA }\end{array}$ & $\begin{array}{l}\text { AACCAATAAAACCTACTCCТCССТT } \\
\text { AA }\end{array}$ \\
\hline AIMI & 15 & CGCGGGTATTGGATGTTAGT & GGGAGCGTTGCGGATTATTCGTAG & CCGACCCACCTATACGAAAA \\
\hline$A P C$ & 14 & GAACCAAAACGCTCCCCAT & CCCGTCGAAAACCCGCCGATTA & $\begin{array}{l}\text { TTATATGTCGGTTACGTGCGTTTAT } \\
\text { AT }\end{array}$ \\
\hline$C A L C A$ & 14 & GTTTTGGAAGTATGAGGGTGACG & $\begin{array}{l}\text { ATTCCGCCAATACACAACAACCAATA } \\
\text { AACG }\end{array}$ & TTCCCGCCGCTATAAATCG \\
\hline CCNA1 & 15 & TCGCGGCGAGTTTATTCG & CGTTATGGCGATGCGGTTTCGG & CCGACCGCGACAAACG \\
\hline$C C N D 2$ & 16 & TTTGATTTAAGGATGCGTTAGAGTACG & AATCCGCCAACACGATCGACCCTA & $\begin{array}{l}\text { ACTTTCTCCCTAAAAACCGACTA } \\
\text { CG }\end{array}$ \\
\hline $\mathrm{CDH1}$ & 14 & AATTTTAGGTTAGAGGGTTATCGCGT & CGCCCACCCGACCTCGCAT & TCCCCAAAACGAAACTAACGAC \\
\hline$C D K N 2 A$ & 17 & TTATTAGAGGGTGGGGCGGATCGC & AGTAGTATGGAGTCGGCGGCGGG & GACCCCGAACCGCGACCGTAA \\
\hline$C D K N 2 B$ & 14 & AGGAAGGAGAGAGTGCGTCG & $\begin{array}{l}\text { TTAACGACACTCTTCCCTTCTTTCCCA } \\
\text { CG }\end{array}$ & CGAATAATCCACCGTTAACCG \\
\hline$D A P K$ & 17 & GGATAGTCGGATCGAGTTAACGTC & $\begin{array}{l}\text { TTCGGTAATTCGTAGCGGTAGGGTTT } \\
\text { GG }\end{array}$ & CCCTCCCAAACGCCGA \\
\hline ESR1 & 14 & GGCGTTCGTTTTGGGATTG & CGATAAAACCGAACGACCCGACGA & GCCGACACGCGAACTCTAA \\
\hline GSTP1 & 18 & AGTTGCGCGGCGATTTC & CGGTCGACGTTCGGGGTGTAGCG & GCCCCAATACTAAATCACGACG \\
\hline HIN1 & 19 & TAGGGAAGGGGGTACGGGTTT & ACTTCCTACTACGACCGACGAACC & CGCTCACGACCGTACCCTAA \\
\hline$M G M T$ & 17 & CGAATATACTAAAACAACCCGCG & AATCCTCGCGATACGCACCGTTTACG & GTATTTTTTCGGGAGCGAGGC \\
\hline MINT31 & 15 & GAGTGATTTATTAGGTTTCGTC & ACGCCGAAAAACACTTCCCCAAC & CGAAAACGAAACGCCGCGA \\
\hline MLH1 & 14 & $\begin{array}{l}\text { CGTTATATATCGTTCGTAGTATTCGTGT } \\
\text { TT }\end{array}$ & CGCGACGTCAAACGCCACTACG & CTATCGCCGCCTCATCGT \\
\hline$M T 1 G$ & 20 & CGTTTAAGGGATTTTGTATTTGGTTTAT & CGCGATCCCGACCTAAACTATACGCA & CCGCTAAATCCGCACCG \\
\hline P14ARF & 14 & ACGGGCGTTTTCGGTAGTT & CGACTCTAAACCCTACGCACGCGAAA & CCGAACCTCCAAAATCTCGA \\
\hline PTGS2 & 14 & CGGAAGCGTTCGGGTAAAG & $\begin{array}{l}\text { TTTCCGCCAAATATCTTTTCTTCTTC } \\
\text { GCA }\end{array}$ & AATTCCACCGCCCCAAAC \\
\hline$R A R B$ & 21 & GGGATTAGAATTTTTTATGCGAGTTGT & TGTCGAGAACGCGAGCGATTCG & TACCCCGACGATACCCAAAC \\
\hline RASSF1A & 16 & GCGTTGAAGTCGGGGTTC & ACAAACGCGAACCGAACGAAACCA & CCCGTACTTCGCTAACTTTAAACG \\
\hline RB1 & 14 & TTAGTTCGCGTATCGATTAGCG & TCACGTCCGCGAAACTCCCGA & ACTAAACGCCGCGTCCAA \\
\hline SFRP1 & 20 & GAATTCGTTCGCGAGGGA & CCGTCACCGACGCGAAAACCAAT & AAACGAACCGCACTCGTTACC \\
\hline SOCS1 & 22 & GCGTCGAGTTCGTGGGTATTT & $\begin{array}{l}\text { ACAATTCCGCTAACGACTATCGCG } \\
\text { CA }\end{array}$ & CCGAAACCATCTTCACGCTAA \\
\hline THBS1 & 23 & CGACGCACCAACCTACCG & ACGCCGCGCTCACCTCCCT & GTTTTGAGTTGGTTTTACGTTCGTT \\
\hline TIMP3 & 23 & GCGTCGGAGGTTAAGGTTGTT & AACTCGCTCGCCCGCCGAA & CTCTCCAAAATTACCGTACGCG \\
\hline
\end{tabular}

(70\%), RASSF1A (70\%), SCGB3A1 (40\%), and SOCS1 (60\%) were frequently methylated (Table 3 ). Those genes that showed a high methylation frequency in hepatoblastoma (namely $A P C, C C N D 2, C D H 1, S C G B 3 A 1, M T 1 G, P T G S 2$, RASSF 1A, and SOCS1) were tested in 10 additional cases and five normal controls.

We found that RASSF $1 A$ was methylated in $80 \%$ of all analyzed cases (16 of 20), PTGS2 and MT1G in 55\% (11 of 20), SOCS1 in 40\% (8 of 20), APC, CCND2, and CDH1 in $30 \%$ (6 of 20), and SCGB3Al in 25\% (5 of 20) (Table 3 and Fig. 1). We also observed that $95 \%$ of neoplastic samples presented methylation for at least one of these eight genes.

Although CCND2, SCGB3A1, and PTGS2 genes are methylated in hepatoblastoma, they are also methylated in the control fetal normal liver samples and, for this reason, are not good candidates for tumor markers. Moreover, the methylation of $A P C, C D H 1, M T 1 G, R A S S F 1 A$, and SOCS1 seems to be specific to tumor samples because no hypermethylation for these genes was detected in the control samples (Table 3 and Fig. 1).

Methylation levels and clinical-pathologic correlations. The methylation pattern of APC, CDH1, MT1G, RASSF1A, and SOCS1 was analyzed for potential correlations with clinical characteristics of patients with hepatoblastoma, including age, histologic subtype, PRETEXT stage, SIOPEL risk group
(25), and presence of metastasis at diagnosis. No significant correlation was observed between these clinical features and methylation status of the genes tested.

The 5-y OS was $74.67 \%$. There was no significant difference in OS by age, histologic subtype and PRETEXT stage. But, SIOPEL risk-based stratification $(55.5 \%$ high risk versus $100 \%$ standard risk; $p=0.0217$ ) and presence of metastasis at diagnosis $(92.8 \%$ localized versus $33.3 \%$ metastatic; $p=$ 0.0066) influenced the OS. Furthermore, the log-rank test comparing OSs showed that MT1G hypermethylation was also correlated with poor prognosis ( $p=0.0431$; Fig. 2).

In addition, a Cox regression univariate model analysis showed a significant positive association between the increase of MT1G methylation and bad prognosis for patients with hepatoblastoma ( $p=0.033$; Table 4).

\section{DISCUSSION}

The analysis of the clinical and epidemiologic characteristics of the cases analyzed here showed that they are similar to those included in earlier studies (3).

Many studies have described the importance of DNA methylation in the extinction of tumor suppressor gene activity in many human cancers. Considerable variations exist in promoter methylation profiles of different cancers, such that 
Table 2. Clinical characteristics of patients with hepatoblastoma at diagnosis

\begin{tabular}{|c|c|}
\hline Patient characteristics & Number of patients $(\%)$ \\
\hline Total & $20(100)$ \\
\hline \multicolumn{2}{|l|}{ Gender } \\
\hline Male & $13(65.0)$ \\
\hline Female & $7(35.0)$ \\
\hline \multicolumn{2}{|l|}{ Age (mo) } \\
\hline Median age & 23.89 \\
\hline Range & $0.36-83.68$ \\
\hline$\geq 24$ & $7(35.0)$ \\
\hline$<24$ & $13(65.0)$ \\
\hline \multicolumn{2}{|l|}{ Time of symptoms (mo) } \\
\hline Median & 3 \\
\hline Range & $0-12$ \\
\hline \multicolumn{2}{|l|}{ SIOPEL PRETEXT } \\
\hline I & $0(0.0)$ \\
\hline II & $3(15.0)$ \\
\hline III & $9(45.0)$ \\
\hline IV & $8(40.0)$ \\
\hline \multicolumn{2}{|l|}{ Metastasis at diagnosis } \\
\hline Yes & $6(30.0)$ \\
\hline No & $14(70.0)$ \\
\hline \multicolumn{2}{|l|}{ Alpha-fetoprotein level at diagnosis } \\
\hline$>100 \mathrm{ng} / \mathrm{dL}$ & $14(70.0)$ \\
\hline$<100 \mathrm{ng} / \mathrm{dL}$ & $2(10.0)$ \\
\hline Not available & $4(20.0)$ \\
\hline \multicolumn{2}{|l|}{ Treatment protocol } \\
\hline Cisplatin/carboplatin/doxorubicin & $10(50.0)$ \\
\hline Cisplatin/carboplatin & $9(45.0)$ \\
\hline Cisplatin & $1(5.0)$ \\
\hline \multicolumn{2}{|l|}{ Response to chemotherapy* } \\
\hline Complete response & $0(0.0)$ \\
\hline Partial response & $12(60.0)$ \\
\hline Stable disease & $4(20.0)$ \\
\hline Progressive disease & $0(0.0)$ \\
\hline Not available & $4(20.0)$ \\
\hline \multicolumn{2}{|l|}{ Resectability } \\
\hline Partial hepatectomy & $14(70.0)$ \\
\hline Segmentectomy & $2(10.0)$ \\
\hline Liver transplantation & $4(20.0)$ \\
\hline \multicolumn{2}{|l|}{ Histology } \\
\hline Mixed fetal and embrionary & $6(30.0)$ \\
\hline Mixed embrionary & $2(10.0)$ \\
\hline Mixed fetal & $7(35.0)$ \\
\hline Pure fetal and embrionary & $2(10.0)$ \\
\hline Pure fetal & $2(10.0)$ \\
\hline Anaplastic & $1(5.0)$ \\
\hline
\end{tabular}

* According to radiological WHO criteria.

individual tumor types have characteristic methylation profiles (9). To date, few studies evaluated gene hypermethylation in hepatoblastoma (10-12,26,27). All of these studies relied on conventional MSP. Therefore, this study is the first to use QMSP to examine the methylation profile of this pediatric hepatic malignancy. QMSP is a real-time PCR-based assay that is more sensitive (it is capable of detecting methylated alleles in a background of normal at a threshold of 1 of 1,000 to 1 of 10,000 ) and more specific than conventional MSP since, in addition to the two PCR primers, the fluorescentlabeled hybridization probe must anneal correctly (23). We used QMSP to test a panel of 25 genes that include eight genes already reported to be methylated in this malignancy by conventional MSP assay (APC, CDH1,CDKN2A, DAPK GSTP1, MGMT, RAR $\beta$ e RASSF1A) and 17 genes never
Table 3. Promoter methylation frequency for the 25 genes analyzed in hepatoblastoma samples and in the normal control group $(n=5)$, pilot group $(n=10)$, and total group $(n=20)$

\begin{tabular}{|c|c|c|c|}
\hline \multirow[b]{2}{*}{ Genes } & \multicolumn{2}{|c|}{$\begin{array}{c}\text { Hepatoblastoma samples, } \\
\mathrm{n}(\%)\end{array}$} & \multirow{2}{*}{$\begin{array}{l}\text { Normal control } \\
\text { samples, n (\%) }\end{array}$} \\
\hline & Pilot group & Total group & \\
\hline$M T 1 G$ & $70(7)$ & $55(11)$ & $0(0)$ \\
\hline$P T G S 2$ & $70(7)$ & $55(11)$ & $100(5)$ \\
\hline RASSF1A & $70(7)$ & $80(16)$ & $0(0)$ \\
\hline$A P C$ & $60(6)$ & $30(6)$ & $0(0)$ \\
\hline SOCS1 & $60(6)$ & $40(8)$ & $0(0)$ \\
\hline CCND2 & $50(5)$ & $30(6)$ & $20(1)$ \\
\hline $\mathrm{CDH1}$ & $50(5)$ & $30(6)$ & $0(0)$ \\
\hline$S C G B 3 A 1$ & $40(4)$ & $25(5)$ & $80(4)$ \\
\hline$R A R \beta$ & $30(3)$ & & \\
\hline$C A L C A$ & $20(2)$ & & \\
\hline$C D K N 2 B$ & $20(2)$ & & \\
\hline ESR1 & $20(2)$ & & \\
\hline SFRP1 & $20(2)$ & & \\
\hline TIMP3 & $20(2)$ & & \\
\hline GSTP1 & $10(1)$ & & \\
\hline AIM1 & $0(0)$ & & \\
\hline CCNA1 & $0(0)$ & & \\
\hline$C D K N 2 A$ & $0(0)$ & & \\
\hline$D A P K$ & $0(0)$ & & \\
\hline$M G M T$ & $0(0)$ & & \\
\hline MINT31 & $0(0)$ & & \\
\hline$M L H 1$ & $0(0)$ & & \\
\hline P14ARF & $0(0)$ & & \\
\hline$R B 1$ & $0(0)$ & & \\
\hline THBS1 & $0(0)$ & & \\
\hline
\end{tabular}

examined in this tumor (AIM1, CALCA, CCNA1, CCND2, CDKN2B, ESR1, MINT31, MLH1, MTIG, P14 ARF, PTGS2, RB1, SCGB3A1, SFRP1, SOCS1, THBS1, and TIMP3).

Because of restrictions in the available amount of DNA isolated from paraffin-embedded tumor samples, we first investigated the panel of 25 genes in 10 tumor cases. As a next step, we analyzed the eight most frequently methylated genes in a second series of cases $(n=10)$. According to the QMSP results, the genes most frequently affected by aberrant methylation in hepatoblastoma are $A P C, C C N D 2, C D H 1$, SCGB3A1, MT1G, PTGS2, RASSF1A, and SOCS1. However, the hypermethylation of CCND2, PTGS2, and SCGB3A1 is not specific (these genes were also found methylated in the normal fetal liver samples).

Except for MGMT, DAPK, and SOCS1, the methylation frequencies found for the genes evaluated in our study are higher than previously reported. This fact could be explained by the higher sensibility of the QMSP method in relation to conventional MSP. However, it is important to note that precautions should be taken when comparing results of different studies concerning aberrant promoter methylation. Although the same tumor type could be evaluated, different methodologies and the use of different primers may yield varied results.

RASSF 1A, the most frequently hypermethylated gene in our samples (80\%), encodes a protein similar to the RAS effector protein (Nore1). This protein seems to interact with the DNA repair protein XPA and inhibits cyclin D1 accumulation, stopping the cell cycle. There are evidences that the lost or 

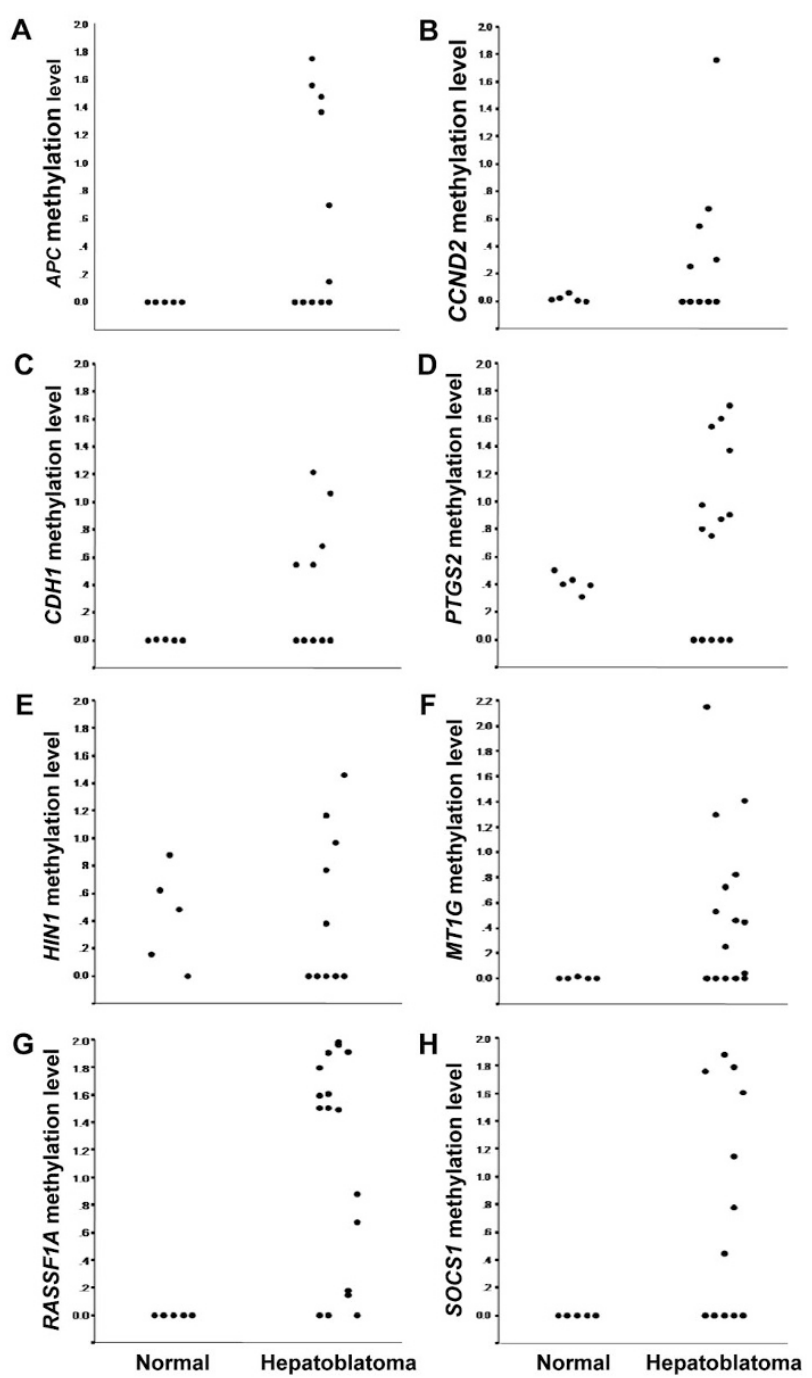

Figure 1. Patterns of hypermethylation observed for the eight selected genes in hepatoblastoma (cases) and fetal normal liver (control). X axis, proportion of methylated cases/tested cases for each sample type. Y axis, quantity of hypermethylation as $\log (\mathrm{PMR}+1)$ where PMR was calculated by the equation (methylated target gene in the sample/ACTB in the sample)/ (methylated target gene in the reference/ACTB in the reference) and the reference was a in vitro methylated DNA sample. (A) APC, (B) CCND2, $(C)$ CDH1, (D) PTGS2, (E) SCGB3A1, (F) MT1G, (G) RASSF1A, (H) SOCS1.

altered expression of this gene is associated with lung, colorectal, breast, and hepatocarcinoma pathogenesis $(28-30)$. Harada et al. (10), using conventional MSP to analyze 27 hepatoblastoma samples, described the hypermethylation of RASSFIA (19\%), RAR $\beta$ (4\%), and GSTPI (4\%) and they could not detect methylation in CDKN2A, MGMT, APC, $D A P K, C D H 1$, and $C D H 13$. In another study, Sugawara et al., (27) using MSP and bisulfite-modified DNA sequencing, detected RASSF1A hypermethylation in $38.5 \%$ of 39 patients with hepatoblastoma. It is important to note that there is a relevant difference between the study of Sugawara et al. and ours. In the former, all samples were obtained from patients without neoadjuvant chemotherapy, whereas ours were collected after chemotherapy exposure. Therefore, one can ask if the chemotherapy effect on the tumor could be related to the difference in RASSFIA methylation profile observed in two

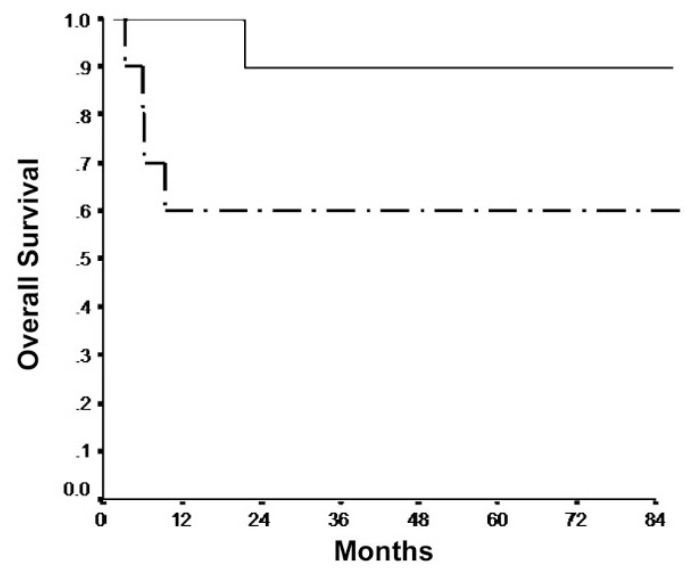

Figure 2. Kaplan-Meier survival curve according to $M T 1 G$ hypermethylation. The 5-y overall survival for the nonmethylated group (solid line) was $90 \%$, whereas the 5-y overall survival for the hypermethylated group (broken line $)$ was $60 \%(p=0.0431)$.

Table 4. Cox regression model comparing methylation level and overall survival

\begin{tabular}{lrc}
\hline Gene & $\beta$ risk & $p^{*}$ \\
\hline APC & 1.654 & 0.476 \\
CDH1 & -15.816 & 0.395 \\
MT1G & 2.196 & 0.033 \\
RASSF1A & 0.007 & 0.995 \\
SOCS1 & -5.222 & 0.271 \\
\hline
\end{tabular}

* Cox regression univariate model.

studies (38.5 versus $80 \%)$. In fact, Koul et al. (31) related high frequency of RASSF1A hypermethylation in cisplatin-resistant germ cell tumors. Therefore, it is possible that 1 ) cisplatin treatment is able to stimulate RASSF1A hypermethylation or 2) the exposure to this drug allows the selection of chemoresistant clones (making these clones more abundant in the selected specimen). If this second hypothesis is true, a high RASSF 1A hypermethylation in hepatoblastoma samples before cisplatin-based therapy should indicate cisplatin resistance and could be useful as a drug-resistance predictor. This hypothesis remains to be confirmed by additional studies.

APC protein is evolved with the CTNNB1 degradation and Wnt signaling pathway. Germ-line defects $A P C$ gene are related with familial adenomatous polyposis (FAP), Gardner and Turcot syndromes (32). As previously mentioned, patients with FAP have increased risk for development of hepatoblastoma (2). So, $A P C$ inactivation seems to be a mechanism associated with the hepatoblastoma pathogenesis and we found $30 \%$ of hypermethylation in this gene in our cases.

$\mathrm{CDHl}$ encodes the adhesion glycoprotein cadherin. Mutations in this gene are associated with gastric, breast, colorectal, thyroid, and ovarian cancers. It is thought that the loss of function of cadherin may be related with cancer progression by increasing proliferation, invasion, and metastasis (33-35). Some studies have demonstrated the correlation between Wntpathway alterations and genesis and/or prognosis of hepatoblastoma $(36,37)$. Considering that $C D H 1$ is a member of the Wnt-pathway maybe its silencing by aberrant methylation could contribute to the genesis of hepatoblastoma. We detected $60 \%$ of tumors with hypermethylated $C D H 1$. 
SOCS1 encodes a JAK-ligand protein, which regulates the cytosine-dependent signal transduction in the JAK/STAT pathway. The absence of SOCS could stimulate the kinase activity of JAK, promoting cell proliferation (38). The association between hypermethylation and transcriptional silencing of SOCS1 has already been reported in hepatoblastoma (12). In this study, they analyzed 15 patients with hepatoblastoma and found $46.6 \%$ of SOCS1 hypermethylation. This frequency is similar to our findings (40\%) and suggests a participation of SOCS1 in hepatoblastoma carcinogenesis.

$M T 1 G$ encodes the metallothionein subtype $1 \mathrm{G}$, a cysteinerich residues protein that binds several heavy metals. Apparently, its biologic function is related to zinc and copper homeostasis and with cadmium toxicity protection. Jahroudi et al. (39) described a higher gene transcriptional activity of $M T 1 G$ associated with heavy metals and dexamethasone exposure in cell line. Nagata et al. (40) compared the expression pattern of hepatoblastoma and normal liver tissue by microarray and found that $M T 1 G$ was hypoexpressed in the tumor. Henrique et al. (41) demonstrated that MTIG hypermethylation was associated with advanced stages of prostate cancer. In addition, $M T 1 G$ hypermethylation was not found in any normal prostate tissue in this study, which indicates that this molecular alteration should be associated with pathologic states. In our study, MTIG presented a high-specific hypermethylation frequency $(55 \%)$ in the hepatoblastoma samples.

Another objective of this study was to investigate whether gene hypermethylation could be associated with clinical parameters, and particularly OS. Previous studies have failed to demonstrate association between methylation profile and clinical features of patients with hepatoblastoma (10-12,26,27). This study, for the first time, demonstrated a strong association between $M T 1 G$ methylation level and poor outcome of patients with hepatoblastoma. According to our results, it seems that the higher the $M T 1 G$ hypermethylation level in the tumor, the lower the patient OS.

In this study, despite the rarity of hepatoblastoma, we evaluate the hypermethylation pattern of 25 genes in 20 cases. We report for the first time that $A P C, C D H 1, M T I G$, and SOCS1 are frequent targets of aberrant methylation in this malignancy and also demonstrate that $M T I G$ hypermethylation correlates significantly to bad prognosis of patients with hepatoblastoma.

Our results, together with other findings, demonstrate that aberrant promoter methylation is a frequent event also in hepatoblastoma and suggest that patients with hepatoblastoma may benefit from demethylating drug treatments.

In summary, this study represents the first quantitative evaluation of the methylation profile of hepatoblastoma and our data provide further evidence that the methylation pattern may be useful as a prognostic indicator in this malignancy.

Acknowledgments. We thank Dr. André L. Carvalho for his assistance with statistical analysis and Dr. Benjamin Heck for kindly providing the fetal liver samples.

\section{REFERENCES}

1. Aronson DC, Schnater JM, Staalman CR, Weverling GJ, Plaschkes J, Perilongo G, Brown J, Phillips A, Otte JB, Czauderna P, MacKinlay G, Vos A 2005 Predictive value of the pretreatment extent of disease system in hepatoblastoma: results from the International Society of Pediatric Oncology Liver Tumor Study Group SIOPEL-1 study. J Clin Oncol 23:1245-1252

2. Herzog CE, Andrassy RJ, Eftekhari F 2000 Childhood cancers: hepatoblastoma Oncologist 5:445-453

3. Fuchs J, Rydzynski J, Von Schweinitz D, Bode U, Hecker H, Weinel P, Bürger D, Harms D, Erttmann R, Oldhafer K, Mildenberger H; Study Committee of the Cooperative Pediatric Liver Tumor Study Hb 94 for the German Society for Pediatric Oncology and Hematology 2002 Pretreatment prognostic factors and treatment results in children with hepatoblastoma: a report from the German Cooperative Pediatric Liver Tumor Study HB 94. Cancer 95:172-182

4. Schnater JM, Köhler SE, Lamers WH, von Schweinitz D, Aronson DC 2003 Where do we stand with hepatoblastoma? A review. Cancer 98:668-678

5. Herman JG, Baylin SB 2003 Gene silencing in cancer in association with promoter hypermethylation. N Engl J Med 349:2042-2054

6. Garinis GA, Patrinos GP, Spanakis NE, Menounos PG 2002 DNA hypermethylation: when tumour suppressor genes go silent. Hum Genet 111:115-127

7. Laird PW 2003 The power and the promise of DNA methylation markers. Nat Rev Cancer 3:253-266

8. Costello JF, Fruhwald MC, Smiraglia DJ, Rush LJ, Robertson GP, Gao X, Wright FA, Feramisco JD, Peltomaki P, Lang JC, Schuller DE, Yu L, Bloomfield CD, Caligiuri MA, Yates A, Nishikawa R, Su HH, Petrelli NJ, Zhang X, O’Dorisio MS, Held WA, Cavenee WK, Plass C 2000 Aberrant CpG-island methylation has non-random and tumour-type-specific patterns. Nat Genet 24:132-138

9. Esteller M, Corn PG, Baylin SB, Herman JG 2001 A gene hypermethylation profile of human cancer. Cancer Res 61:3225-3229

10. Harada K, Toyooka S, Maitra A, Maruyama R, Toyooka KO, Timmons CF, Tomlinson GE, Mastrangelo D, Hay RJ, Minna JD, Gazdar AF 2002 Aberrant promoter methylation and silencing of the RASSF1A gene in pediatric tumors and cell lines. Oncogene 21:4345-4349

11. Shim YH, Park HJ, Choi MS, Kim JS, Kim H, Kim JJ, Jang JJ, Yu E 2003 Hypermethylation of the p16 gene and lack of p16 expression in hepatoblastoma. Mod Pathol 16:430-436

12. Nagai H, Naka T, Terada Y, Komazaki T, Yabe A, Jin E, Kawanami O, Kishimoto T, Konishi N, Nakamura M, Kobayashi Y, Emi M 2003 Hypermethylation associated with inactivation of the SOCS-1 gene, a JAK/STAT inhibitor, in human hepatoblastomas. J Hum Genet 48:65-69

13. Vidal DO, Paixao VA, Brait M, Souto EX, Caballero OL, Lopes LF, Vettore AL 2007 Aberrant methylation in pediatric myelodysplastic syndrome. Leuk Res 31:175-181

14. Eads CA, Lord RV, Wickramasinghe K, Long TI, Kurumboor SK, Bernstein L, Peters JH, DeMeester SR, DeMeester TR, Skinner KA, Laird PW 2001 Epigenetic patterns in the progression of esophageal adenocarcinoma. Cancer Res 61:34103418

15. Carvalho AL, Jeronimo C, Kim MM, Henrique R, Zhang Z, Hoque MO, Chang S, Brait M, Nayak CS, Jiang WW, Claybourne Q, Tokumaru Y, Lee J, Goldenberg D, Garrett-Mayer E, Goodman S, Moon CS, Koch W, Westra WH, Sidransky D, Califano JA 2008 Evaluation of promoter hypermethylation detection in body fluids as a screening/diagnosis tool for head and neck squamous cell carcinoma. Clin Cancer Res 14:97-107

16. Lehmann U, Länger F, Feist H, Glöckner S, Hasemeier B, Kreipe H 2002 Quantitative assessment of promoter hypermethylation during breast cancer development. Am J Pathol 160:605-612

17. Harden SV, Tokumaru Y, Westra WH, Goodman S, Ahrendt SA, Yang SC, Sidransky D 2003 Gene promoter hypermethylation in tumors and lymph nodes of stage I lung cancer patients. Clin Cancer Res 9:1370-1375

18. Jerónimo C, Usadel H, Henrique R, Oliveira J, Lopes C, Nelson WG, Sidransky D 2001 Quantitation of GSTP1 methylation in non-neoplastic prostatic tissue and organ-confined prostate adenocarcinoma. J Natl Cancer Inst 93:1747-1752

19. Fackler MJ, McVeigh M, Mehrotra J, Blum MA, Lange J, Lapides A, Garrett E, Argani P, Sukumar S 2004 Quantitative multiplex methylation-specific PCR assay for the detection of promoter hypermethylation in multiple genes in breast cancer. Cancer Res 64:4442-4452

20. Weisenberger DJ, Siegmund KD, Campan M, Young J, Long TI, Faasse MA, Kang GH, Widschwendter M, Weener D, Buchanan D, Koh H, Simms L, Barker M, Leggett B, Levine J, Kim M, French AJ, Thibodeau SN, Jass J, Haile R, Laird PW 2006 CpG island methylator phenotype underlies sporadic microsatellite instability and is tightly associated with BRAF mutation in colorectal cancer. Nat Genet 38:787-793

21. Hoque MO, Topaloglu O, Begum S, Henrique R, Rosenbaum E, Van Criekinge W, Westra WH, Sidransky D 2005 Quantitative methylation-specific polymerase chain reaction gene patterns in urine sediment distinguish prostate cancer patients from control subjects. J Clin Oncol 23:6569-6575

22. Müller HM, Widschwendter A, Fiegl H, Ivarsson L, Goebel G, Perkmann E, Marth C, Widschwendter M 2003 DNA methylation in serum of breast cancer patients: an independent prognostic marker. Cancer Res 63:7641-7645

23. Eads CA, Danenberg KD, Kawakami K, Saltz LB, Blake C, Shibata D, Danenberg PV, Laird PW 2000 MethyLight: a high-throughput assay to measure DNA methylation. Nucleic Acids Res 28:E32

24. Roebuck DJ, Aronson D, Clapuyt P, Czauderna P, de Ville de Goyet J, Gauthier F, Mackinlay G, Maibach R, McHugh K, Olsen OE, Otte JB, Pariente D, Plaschkes J, Childs M, Perilongo G; International Childhood Liver Tumor Strategy Group 2007 
2005 PRETEXT: a revised staging system for primary malignant liver tumours of childhood developed by the SIOPEL group. Pediatr Radiol 37:123-132

25. Czauderna P, Otte JB, Aronson DC, Gauthier F, MacKinlay G, Roebuck D Plaschkes J, Perilongo G 2005 Guidelines for surgical treatment of hepatoblastoma in the modern era-recommendations from the Childhood Liver Tumour Strategy Group of the International Society of Paediatric Oncology (SIOPEL). Eur J Cancer 41:1031-1036

26. Fukuzawa R, Umezawa A, Ochi K, Urano F, Ikeda H, Hata J 1999 High frequency of inactivation of the imprinted H19 gene in "sporadic" hepatoblastoma. Int J Cancer $82: 490-497$

27. Sugawara W, Haruta M, Sasaki F, Watanabe N, Tsunematsu Y, Kikuta A, Kaneko Y 2007 Promoter hypermethylation of the RASSF1A gene predicts the poor outcome of patients with hepatoblastoma. Pediatr Blood Cancer 49:240-249

28. Tsou JA, Galler JS, Siegmund KD, Laird PW, Turla S, Cozen W, Hagen JA, Koss MN, Laird-Offringa IA 2007 Identification of a panel of sensitive and specific DNA methylation markers for lung adenocarcinoma. Mol Cancer 6:70

29. Wang YC, Yu ZH, Liu C, Xu LZ, Yu W, Lu J, Zhu RM, Li GL, Xia XY, Wei XW, Ji HZ, Lu H, Gao Y, Gao WM, Chen LB 2008 Detection of RASSF1A promoter hypermethylation in serum from gastric and colorectal adenocarcinoma patients. World J Gastroenterol 14:3074-3080

30. Yeo W, Wong WL, Wong N, Law BK, Tse GM, Zhong S 2005 High frequency of promoter hypermethylation of RASSF1A in tumorous and non-tumourous tissue of breast cancer. Pathology 37:125-130

31. Koul S, McKiernan JM, Narayan G, Houldsworth J, Bacik J, Dobrzynski DL, Assaad AM, Mansukhani M, Reuter VE, Bosl GJ, Chaganti RS, Murty VV 2004 Role of promoter hypermethylation in Cisplatin treatment response of male germ cell tumors. Mol Cancer 3:16

32. Foulkes WD 1995 A tale of four syndromes: familial adenomatous polyposis, Gardner syndrome, attenuated APC and Turcot syndrome. QJM 88:853-863

33. Barber M, Murrell A, Ito Y, Maia AT, Hyland S, Oliveira C, Save V, Carneiro F, Paterson AL, Grehan N, Dwerryhouse S, Lao-Sirieix P, Caldas C, Fitzgerald RC
2008 Mechanisms and sequelae of E-cadherin silencing in hereditary diffuse gastric cancer. J Pathol 216:295-306

34. Fujii S, Ochiai A 2008 Enhancer of zeste homolog 2 downregulates E-cadherin by mediating histone H3 methylation in gastric cancer cells. Cancer Sci 99:738-746

35. Cao Q, Yu J, Dhanasekaran SM, Kim JH, Mani RS, Tomlins SA, Mehra R, Laxman B, Cao X, Yu J, Kleer CG, Varambally S, Chinnaiyan AM 2008 Repression of E-cadherin by the polycomb group protein EZH2 in cancer. Oncogene 27:72747284

36. Blaker H, Hofmann WJ, Rieker RJ, Penzel R, Graf M, Otto HF 1999 Beta-catenin accumulation and mutation of the CTNNB1 gene in hepatoblastoma. Genes Chromosomes Cancer 25:399-402

37. Park WS, Oh RR, Park JY, Kim PJ, Shin MS, Lee JH, Kim HS, Lee SH, Kim SY, Park YG, An WG, Kim HS, Jang JJ, Yoo NJ, Lee JY 2001 Nuclear localization of beta-catenin is an important prognostic factor in hepatoblastoma. J Pathol 193:483490

38. Wu SJ, Yao M, Chou WC, Tang JL, Chen CY, Ko BS, Huang SY, Tsay W, Chen YC, Shen MC, Wang CH, Yeh YC, Tien HF 2006 Clinical implications of SOCS1 methylation in myelodysplastic syndrome. Br J Haematol 135:317-323

39. Jahroudi N, Foster R, Price-Haughey J, Beitel G, Gedamu L 1990 Cell-type specific and differential regulation of the human metallothionein genes. Correlation with DNA methylation and chromatin structure. J Biol Chem 265:6506-6511

40. Nagata T, Takahashi Y, Ishii Y, Asai S, Nishida Y, Murata A, Koshinaga T, Fukuzawa M, Hamazaki M, Asami K, Ito E, Ikeda H, Takamatsu H, Koike K, Kikuta A, Kuroiwa M, Watanabe A, Kosaka Y, Fujita H, Miyake M, Mugishima H 2003 Transcriptional profiling in hepatoblastomas using high-density oligonucleotide DNA array. Cancer Genet Cytogenet 145:152-160

41. Henrique R, Jeronimo C, Hoque MO, Nomoto S, Carvalho AL, Costa VL, Oliveira J, Teixeira MR, Lopes C, Sidransky D 2005 MT1G hypermethylation is associated with higher tumor stage in prostate cancer. Cancer Epidemiol Biomarkers Prev $14: 1274-1278$ 